\title{
STUDI PENDAHULUAN PEMBUATAN FOTOREAKTOR
}

\author{
Nugroho Tri Sanyoto, Toto Trikasjono, Damar \\ Sekolah Tinggi Teknologi Nuklir - Badan Tenaga Nuklir Nasioanal \\ Jl. Babarsari PO BOX 6101/YKBB Yogyakana 55281 \\ Telp : (()274)489085; Fax : (0274)489715 \\ E-mail: trisanyotonugroho ayahoo coid
}

\begin{abstract}
ABSTRAK
STUDT PENDAHULUAN PEMBUATAN FOTOREAKTOR. Telah dilakukan stud pendahuluan penbuatan fotoreaktor yang digunakan untuk melakukan reaksi fotokimia photobiological dengan sistem panas dan penyinaran Ultra violet (UV). Sistem ini terdiri dari mikrokontroler ATMegi 16, keypad matriks $3 \times 4$, pemanas dan penampil LCD (Liquid Crystal Display). Suhu dibangkitkan dengan pernanas dapat diatur wakturya dengan menggunakan keypad. Tcgangan analog yang dihasilkar oleh sensor suhu SITT1 I dan sensor cahaya LDR (Light Dependent Resistor) diolah ADC (Analog to Digital Converter) pada mikrokontroler unluk dikonversikan menjudi nilai suhu dan intensitas cahaya yang terukur. Tampilan pada LCD $16 \times 2$ untuk mempemudah pembacaan. Hasil pengujian alat digunakan sampel akrilamida cair dengan perlakuan panas dan penyinaran berubah menjadi gol.
\end{abstract}

Kata kuici: Fotortuktor, suhu dan sensor, reaksi fotokimia photobiolugical

\section{ABSTRACT}

BEGINNING STUDY FOR MADE OF PHOTOREACTOR. Performed preliminary studies photoreactor used to pesfrim Phorobiological photochemical reaction with heat and system thitra wiolet radiation (UF). This system consists of a microcontroller ATmegal6 matrix keypad $3 \times 4$. heating and viewer LCD iLiguid Cinstal Display). The remperature was ratsed with heating time can be set ussing the keypad. Aralog voljage generafed by the temperature sensor light sinsur SHTII and LDR fLight Dependent Resistor) processed $A D C$ (Analog to Digitul Convertert on the microcontroller to be comerted into values of temperuture and light infensity were measued Displan un $L C D \quad 16 \times 2$ for ease of reoding. Results of testing tools wsed liquid acrylanide samples with hest treatmond and inradiation tams inta gel

Kequords: photoreactar, temperature and sensur, phosobiological photochemical reaction

\section{PENDAHULUAN}

Penelitian ini metupakan kajian awal penggunaan teknik foto-oksidasi UV dan pemanas untuk mengolah limbah warna Akrilamida dalam sebuah fotoreaktor. Efek dari kedua variabel terhadap efektivitas penghitangan kandungan zat warna dalam limbah. Untuk itu diperlukan inovasi dan pengembangan teknologi sebagai solusi bagi pencemaran limbah incustri salah satunya dengan pengembangan teknologi dalam pengolahari limbah eair. Beberapa proses pengolahan limbah cair telah dilakukan seperti proses pengolahan secara kimia, fisika dan biologi. Pada penelitian ini menggunakan sample berupa Akrilamida. akrilamida menupakan senyawa kristalin bening hïngga putib dengan bobot molekul 71,09; tidak berbau, larut dalam air, metanol, etanol, dimetil eter dan aseton, serta tidak larut dalam benzen , heptan dan akrilamida dapat berpotensi kanker terhadap manusia li! Beberapa penelitian menunjukan akrilamida dapat menyebabkan tumor dan kanker pada hewan percobaan. Akrilamida akan meleleh pada suhu $87,5^{\circ} \mathrm{C}$ dan mendidih pada suhu $125^{\circ} \mathrm{C}$. Maka dibuatlah Photorcaktor yang diharapkan dapat dilakukan kajian tebih lanjut. alat ini digunakan untuk memproses suatu limbah industri dengan perlakuan parias 
dengari suhu tertentu serta dengan waktu lerbatas. Fotoreaktor membutuhkan sensor suhu dan sensor cahaya, mikrokontroler dan LCD sęhagar penampif data.

\section{DASAR TEORI}

Fotoreaktor adalah suatu alat yang dapat digunakan untuk memproses suatu limbah industri cair dengan perlakuan panas dan suhu tertentu serta paparan sinar ultra violet $(\mathrm{UV})^{2}$. Alat ini dibuat dengan sensor suhu dan calhaya menggunakan SHTII sebagai sensor suhu dan photodioda sebagai sensor cahaya, sedirgkan mokrokontroler di gunakan adalah ATMega 16, hasil dapar di tampilkan pada LCD (Liquid Crystal Display), Fotoreaktor menggunakan pemanas berupa elemen setrika sebagai media pemanas sedangkan media penyinarannya digunakan lampu UV sebagai pengganti dari cahaya sinar matahari.

\section{Sensor SHT11}

Sensor tipe SHT11 merupakan multi sensor unuk kelembaban dan temperatur secara digital. Sensor tipe SHTI1 menggunakin teknologi CMOS yang telah dipatenkan sehingga menjamin kestabilan dan reliability yang tinggi". Dalam chip ini terdiri dari capacitive polymer sensing element untuk relative humidity seusor dan bandgar temperature sensor. Keduanya dihubungkan pada 14 bit ADC (Analog io Digital Convertion) dan interface serial, di dalam chip itu sendiri. Output yang dihasilkan berupa sinyal, waktu respon yang cepat, fidak sensitif terhadap extemal disturbace, dengan harga yang kompetitif Antarmuka 2-wire serial interface dan internal voltage regulation membuat sistem integrasi yang mudah dan cepat. Juga karena bentukuya yang kecil dan konsumsi powernya yang hemat sensor ini merupakan pilihan yang baik Sensor ini tersedia dalam dua tipe yaitu suffacemonnable LCC (Lealess Chip Carrier) dan pluggable 4-pin single-in-line.

\section{Sensor LDR}

Sensor cahaye adalah alat yang digunakan untuk merubah besaran cahaya menjadi besaran listrik yang dapat dengan mudah dianalisis besarnya ${ }^{[3]}$ Sensor cabaya yang digunakan dalam penelítian ini adalah LDR singkatan dari Light Dependent Resistor adalah resistor yang nilat resistansuya berahah-ubah karena adanya intensitus cahaya yang diserap. LDR adalah salah satu jenis resistor yang dapat mengalami perubahan resistansinya apabila mengalami perubahan penerimaan cahaya. Besarnya nilai hambatan pada Sensor Cahaya LDR tergantung pada besar kecilnya cahaya yang diterima oleh LDR itu sendiri. L.DR sering disebut dengan alat atau sensor yang berupa resistor yang peka terhadip cahaya. Biasanya LDR terbuat dari cadmium sulfida yaitu merupakan bahan semikonduktor yang resistansinya berubahubah menurut banyaknya cahaya (sinar) yang mengenainyz $^{(4)}$. Resistansi LDR pada tempat yang gelap biasanya mencapai sekitat $10 \mathrm{M} \Omega$, dán ditempal terang LDR mempunyai resistansi yang turum menjadi sekitar $150 \Omega$.

\section{Keypad $3 \times 4$}

Tombol keypad matrik $3 \times 4$ adalah susunan dari beberapa buah saklar tekan (push bution) yang disusun secara matrix 15! Dipasaran terdanat beberapa jenis tombol keypad, dan yang sering digunakan diantaranya adalah tombol keypad $3 \times 4$

\section{Mikrokontroler}

Mikrokoniroler merupakan suatu terobosan teknologi mikroprosesor dan mikrokomputer yang menipakan teknologi semikonduktor dengan kandungan transistor yang lebih banyak namun hanya membutuhkan ruang yatg sangat kecil, Lebih lanjut, mikrokontroler merupakan system komputer yang mempunyai satu atau beberapa tugas yang sangat spesifik berbeda dengan PC (Personal Computer) yang memiliki beragam fungsi. Pada sistem komputer perbandingan RAM dan ROM nya besar, artinya programprogram penggunba distmpan dalam ruang RAM yang relative besar, sedangkan ruturutin antar muka perangkat keras disimpan dalam ruang ROM yang kecil, sedangkan pada mikrokontroler, perbandingan ROM dan RAM kecil, artinya program kontrol disimpan dalam ROM (bias Masked ROM atau Flash PEROM) yang ukurannya relatif lebih kecil, sedangkan RAM digunakan sebagai tempat petiyimpanan sementara. termasuk register-pegister yang digunakan pada mikrokontroler yang bersangkutan. 


\section{LCD (Liquid Crystal Display)}

LCD merupakan salah satu perangkat display yang umum dipakai dalam sebuah sistem instrumentasi ${ }^{[0 t}$. Dengan LCD $16 \times 2$ baris, dapat menampilkan informasi dari sebuah pengukuran data sensor, menu pengaturan instrumen, ataupun yang lainnya. LCD tersusun dari dot matrik LCD controller, segmen driver serta LCD panel. Kontroller LCD telah terintegrasi dengan ROM/RAM pembangkit karakter atau CGRAM (Character Generator RAM) dan RAM data display atau DDRAM (Display Data RAM). Berikut adalah Gambar 1 LCD $16 \times 2$

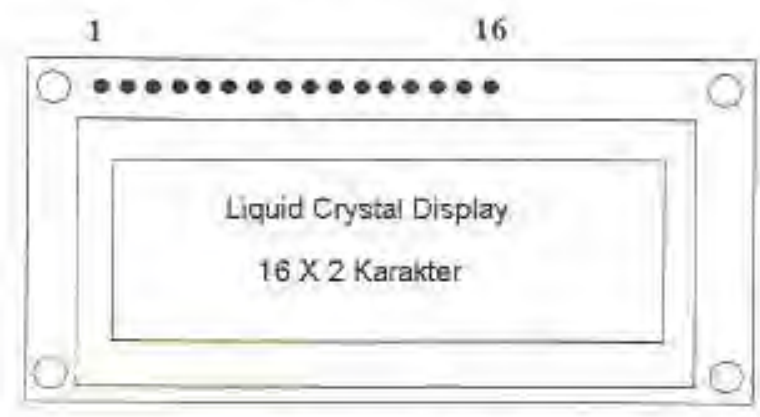

Gambar 1. LCD $16 \times 2$

\section{Pemanas}

Pemanas (heater) merupakan elemen elekronik yang berfingsi sebagai media pemanas mekanik setrika terdiri atas tiga komponen: bimetal, heater: dan lempengan plat besi pemanas. Gambar 2. Heater setrika

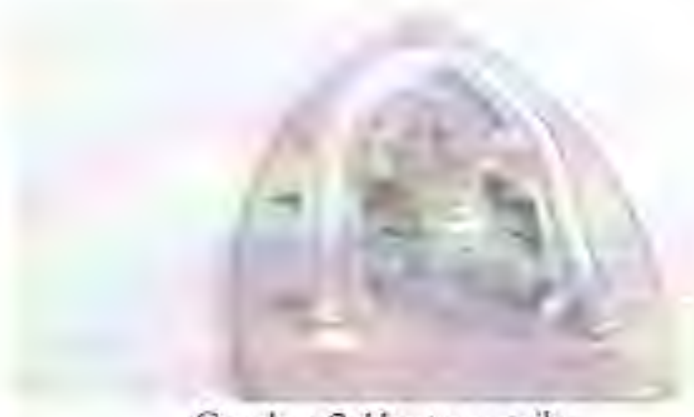

Gambar 2 Heater setrika

\section{Lampu Ultraviolet}

Lampu UV banyak dipakai dalam kehidupan sehari-hari. Fungsi dán lampu ultraviolet bermacam-macam diantaranya ialah dalam kromatografi (menandai spot yang tidak dapat dilihat melalui sinar tampak). Gambar 3 merupakan Lampu UV

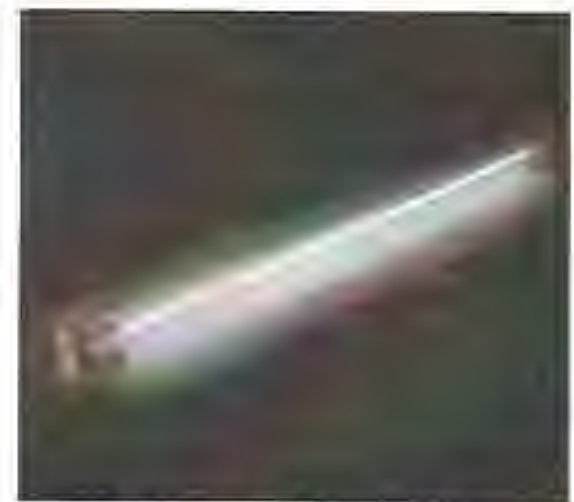

Gambar 3, Lampu UV

Lampu UV memancarkan sinar Ultraviolet yang memiliki kemampuan untuk mempengaruhi fungsi sel makhluk hidup dengan mengubah materi inti sel atau DNA, sehingga makhluk tersebut mati. Jenis lampu ultraviolet tersebut dengan panjang gelombang 200-260 $\mathrm{nm}$ atau lebih dikenal dengan UV C.

\section{METODE}

Blok diagram fotoreaktor

Blok diagram alat Fotoreaktor dapat dilibat pada Gambar 4.

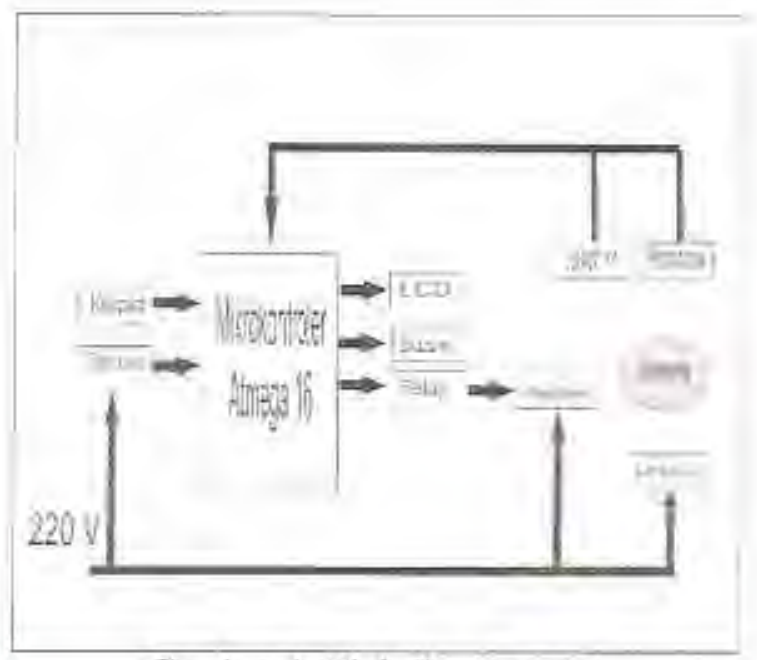

Gambar 4. Blok diagram alat

\section{Cara kerja}

Suhu diatur menggunakan keypad $3 \times 4$ yang diolah oleh mikrokontroler ATMega 16 sebagai batasan suhu ruangan photoreaktor. Tegangan analog yang dihasilkan oleh sensor suhu menjadi masukan ADC bagi mikrokontroler, nilai $\mathrm{ADC}$ ini diolah mikrokontroler untuk dikonversikan menjadi suhu. Hasil konversi dari sensor ditampilkan ke LCD. Sebagai penampil dari suhu, intensitas cahaya dan timer di dalam photoreaktor digunakan LCD dengan $16 \times 2$ karakter. 
Keypad merupakan masukan bagi mikrokontroler yang berupa kode-kode digital yang dikonversikan oleh mikrokontroler ke dalam kode desimal maupun ASCII untuk mengisikan data angka maupun simbol. Sebuah Reypad memiliki tombol yang mempunyai fungsi sesuai dengan pengaturan pembuat alat. Rangkaian sensor suhu dan sensor cahaya dipasang sebelum data masuk ke mikrokontroler. Rangkain ini berfungsi untuk menguatkan tegangan keluaran sensor subu dan sensor cahaya dengan menggunakan IC SHT 11 agar dapat dibaca oleh ADC dikarenakan adanya jarak sensor dengan minimum sistent. Pemanas merupakan penghasil panas di dalam Fotoreaktor. Pemanas dikendalikan mikrokontroler dengan menggunakan relay sehingga apabila suhu di dalam Fotoreaktor melebihi batas suhu yang diinginkan maka mikrokontroler akan memberi perintah pada relay untuk mematikan pemanas. Relay akan menghidupkan pemanas apabila subu di dalam fotoreaktor dibawah suhu yang diinginkan.

\section{Perancangan Perangkat keras}

Rancangan perangkat keras dapat dilihat pada Gambar 5.Rangkaian elektronik dari fotoreaktor dan Gambar 6 Fotoreaktor yang dibuat.

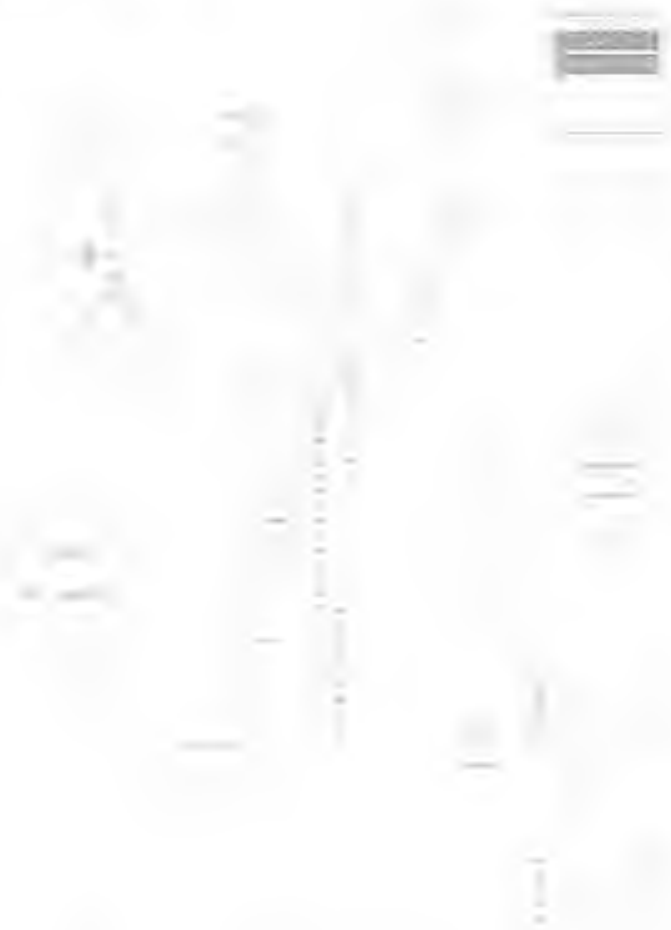

Gambar 5. Rangkaian Elektronik

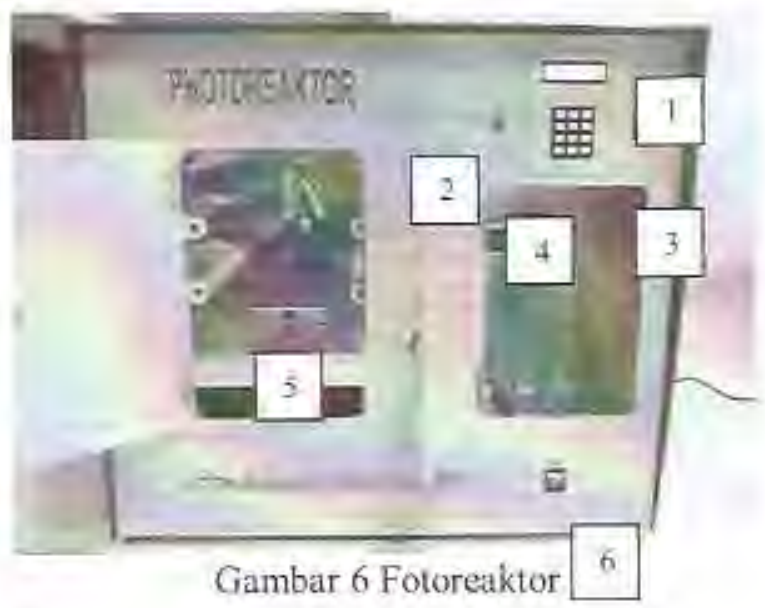

Keterangan gambar :
1. Penampil LCD
2. Tombol Reset
3. Tombol Power Lampu on/off
4. Tombol Keypad
5. Tempat Sample
6. Tombol Power on/off miktokontrol

\section{HASIL DAN PEMBAHASAN}

Pengujian yang dilakukan pada alat dengan meliputi beberapa bagian, yaitu pengujian sensor suhu, pengujian heater, pengujian intensitas cahaya, pengujian bubungat intensitas cahaya dengan daya, pengujian hubungan suhu dengan waktu dan pengujian terhadap suatu sampel.

\section{Pengujian Sensor Suhu}

Sensor suhu diujikan dengan membandingkan sensor suhu SHTII dengan thermometer digital Sanwa model DMM PC 520. Tampilan sensor suhu SHT11 dengan thermometer digital Sanwa model DMM PC 520. Hasil pengujian terdapat pada tabel 1

Tabel 1.Hasil uji SHT 11 dibanding dengan DMM PC500

\begin{tabular}{ccr}
\hline No & $\begin{array}{c}\text { Sht 11( } \\
\left.{ }^{6} \mathrm{C}\right)\end{array}$ & $\begin{array}{c}\text { Thermometer } \\
\text { digital } \\
\text { DMM }\end{array}$ \\
\hline 1. & 33,96 & 32 \\
2. & 38,79 & 38 \\
3. & 47,20 & 47 \\
4. & 60,05 & 60 \\
5. & 73,03 & 73 \\
6. & 83,03 & 83 \\
7. & 86,50 & 86 \\
8. & 85,53 & 83 \\
9. & 85,51 & 85 \\
10. & 86,73 & 86 \\
\hline
\end{tabular}




\section{Pengujian Sensor Cahaya}

Pengujian sensor cahaya dilakukan dengan membandingkan sensor cahaya yang digunakan pada fotoreaktor yaitu LDR dengan alat pembanding yang standar yaitu Liax meter model 407026 dari Extech Instrument. Data hasil pengujian yang dirunjukkan pada Tabel 2.

Tabel 2 hasil uji LDR dengan LUX Meter.

\begin{tabular}{ccl} 
Time & Lux Meter (Lux) & LDR (Lix) \\
\hline 1 & 44 & 43 \\
2 & 44 & 43 \\
3 & 43 & 43 \\
4 & 45 & 43 \\
5 & 45 & 43 \\
6 & 45 & 43 \\
7 & 44 & 43 \\
8 & 45 & 43 \\
9 & 44 & 43 \\
10 & 45 & 43 \\
\hline
\end{tabular}

Tabel 2. Terdapat perbedaan antara nilai yang lerukur puda Lux meter dengan nilai yang terukur oleh LDR, hal ini dikarenakan perbedaan kualitas sensor yang digunakars. LDR merupakan sensor cahaya yang digunakan didalam penelitian ini sedang Lux meter pabrikkan. Perbedaan ini dapat menyebabkan nilai pengukuran yang berbeda, karena tingkat kesensitifan dan respon terhadap cahaya yang mengenai kedua sensor mi pun herbeda. Luas penampang akan berpengaruh terhadap nilai intensitas cahaya. Sernakin besar luas penampang sensor akan membuat sensor semakin banyak menyerap cahaya yang mengenainya. Sebaliknya, semakin kecil penampangnya maka semakin sedikit sensor menyerap cahaya. Sensor yang digunakan pada alat pembanding memiliki luas penampang yang lebih besar đibandingkan dengan luas penampang yang digunakan di dalam penelitian .

\section{Pengujian Intensitas Cahaya dan Daya}

Pengujian ini bertujuan untuk mengetahui hubungan intensitas cahaya terhadap perubahan daya. Daya disini merupakan daya yang berasal dari tiga buah lampu UV di dalam fotoreaktor. Lampu memiliki daya 30 watt, lampu memiliki daya 60 walt dan lampu daya 90 watt.

Gambar 7 adalah merupakan gambar dari hasil ukur antara LDR dengan Lux meter pada Jampu 90 watt. Gambar 8. Adalah merupakan gambar dari hasil ukur pada lampu 60 watt dan Gambar 9 hasil ukr pada lampu 30 watl

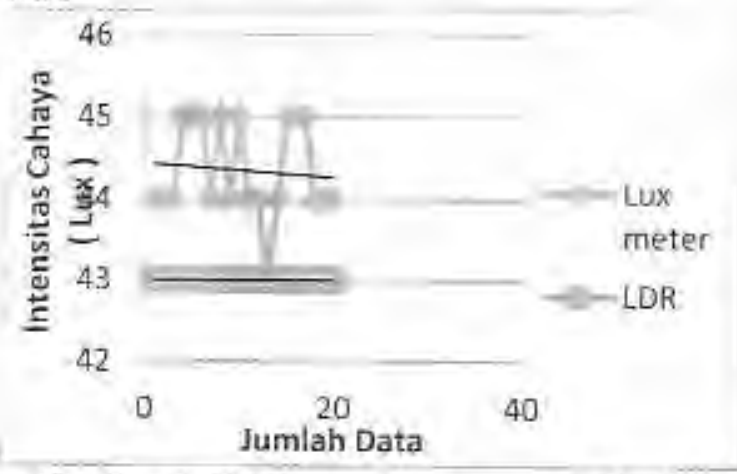

Gambar 7. Hasil pengujian sensor terhadap daya 90 watt

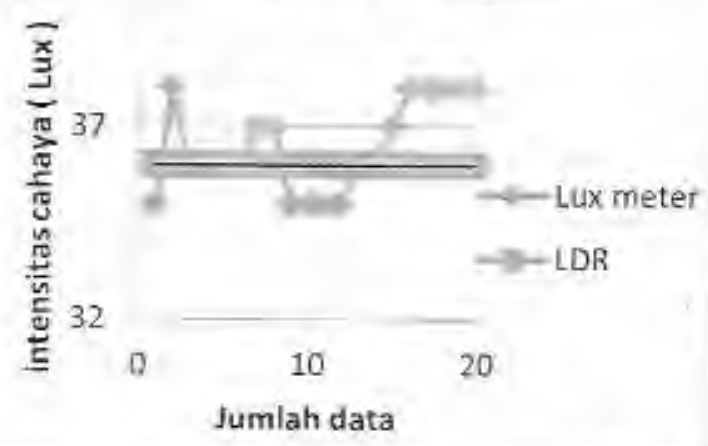

Gambat 8. Hasil pengujian sensor terhadap daya 60 watt

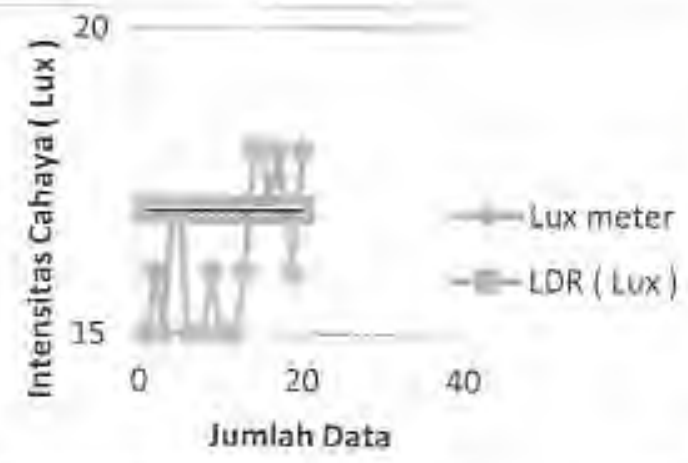

Gambar 9. Hasil pengujian sensor terhadap daya 30 watt

\section{Pengujian Seusor Suhu dengan Waktu}

Pengujian pemanas bertujuan untuk mengetahui waktu panas yang diperlukan dan panas maksimal yang dihasilkan oleh pemanas dalam fotoreaktor. Thermometer digital Sanwa 
model DMMPC 520 sebagai pembanding perunjukkan suhu. Pengujian dilakukan dengan mengamati berapa lama waktu yang dibutuhkan pemanas untuk mencapai subu maksimalnya. Posisi kedua sensor tersebut diletakkan secara verikal pada dinding chasing. Tabel 3 adalah daata hasil pengujian suhu dari Sensor SHT II serta suhu yang diukur thermorneter digital Model DMM PC 520

Dari tabel 3 ternyata hasil ukur dari sensor SHT11 dan thermometer digital ModeI DMM PC 520 untuk mencapai suhu yang bersamaan pada menit ke 6 , akan tetapi hasil akhir dari data pengujian yang diperoleh subu maksimal pada sensor SHT 11 adalah $86,73^{\circ} \mathrm{C}$ sedangkan pada thermometer digital model DMM PC 520 adalah $85^{\circ} \mathrm{C}$

Tabel 3. Hasil uji Sensor

\begin{tabular}{ccc}
\hline No & $\begin{array}{l}\text { Suhu } \\
\text { SHTII }\end{array}$ & $\begin{array}{l}\text { Thermometer waktu } \\
\text { digital model } \\
\left({ }^{\circ} \mathrm{C}\right)\end{array}$ \\
& DMM PC \\
& $520\left({ }^{\circ} \mathrm{C}\right)$ \\
\hline
\end{tabular}

\begin{tabular}{llll}
1 & 33,96 & 32 & 00.00 .59 \\
2 & 38,79 & 37 & 00.01 .59 \\
3 & 47,20 & 47 & 00.02 .59 \\
4 & 60,05 & 59 & $00.03,59$ \\
5 & 74.03 & 70 & 00.04 .59 \\
6 & 83,03 & 81 & 00.05 .59 \\
7 & 86,50 & 85 & 00.06 .59 \\
8 & 83,53 & 83 & 00.07 .59 \\
9 & 85,51 & 82 & 00.08 .59 \\
10 & 86,73 & 85 & 00.09 .59 \\
11 & 83,86 & 83 & 00.10 .59 \\
12 & 82,51 & 80 & 00.11 .59 \\
13 & 84,39 & 83 & 00.12 .59 \\
14 & 86,02 & 84 & 00.13 .59 \\
15 & 86,17 & 84 & 00.14 .59 \\
\hline
\end{tabular}

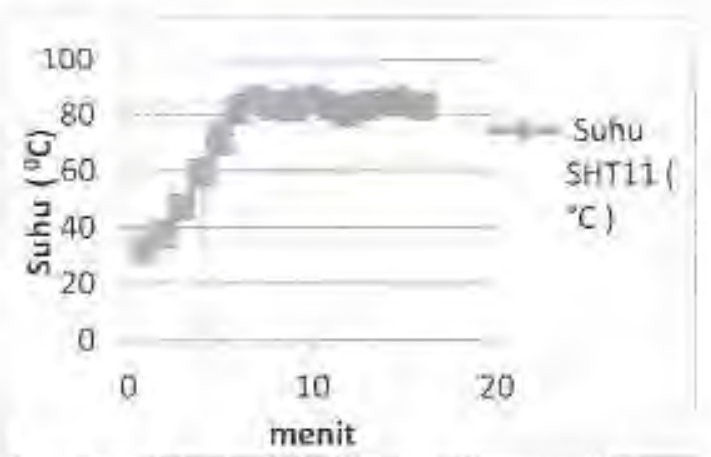

Gambar 10. Hasil uji sensor dengan waktu

\section{Pengujian Sample Terhadap Panas dan sinar}

Pengujian ini dilakukan dengan tujuan untuk mengetahui perubahan yang terjadi pada sample, yang dimasukan pada ruang dalam fotoreaktor. Sample yang digunakan dalam penelitian ini adalah Akrilamida dengan dicampurkan methylene orange sebagai indikator warna. Pada pengujian ini sample diletakkan dalam fotoreaktor dengan cara perlakuan panas dan penyinaran, Gambar 10(A) merupakan sampel berupa cairan berwatna merah sebelum di uji pada fotoreaktor, sedangkan pada Gambar 10 ( B) Hasil uji coba berupa gel, pada saat sampel diperlakukan panas pada suhu mencapai $54,83^{\circ} \mathrm{C}$ dan keadaan lampu UV nyala semua atau dengan daya 90 watt lampu. Gambar IO(C) adalah hasil dari uji coba berupa gel yang tidak berwarna (bening).

Dari hasil percobaan tersebut alat fotoreaktor dapat mendegradasikan warna suatu sampel dari warna semula merah menjadi bening tak berwarna dan pérubahan wujud sampel dari cair menjadi padat menyerupai gel. Hal ini disebabkan panas dan penyinaran pada fotoreaktor memiliki energi yang dapat mengubah suatu sampel dari wajud cair menjadi padat (berupa gel). Pada saat pengujian sampel diperlakuan panas dan penyinaran suhu dalam fotoreaktor mencapai $54,83{ }^{\circ} \mathrm{C}$ pada keadaan lampu UV nyala semua dengan daya 90 watt lampu, sehingga mempercepat perubahan reaksi yang dialami pada suatu sampel materi. 


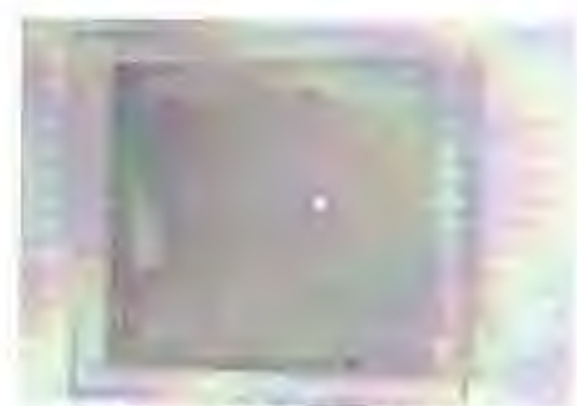

A. Sampel akrilamida cair

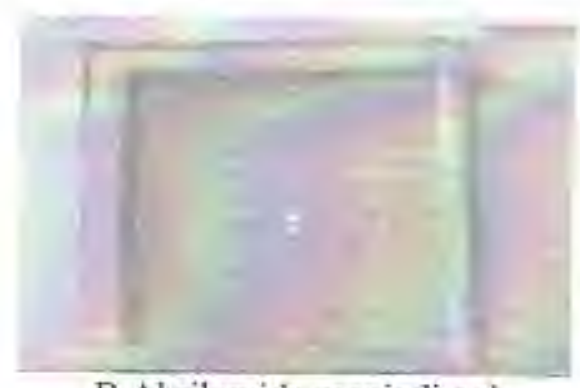

B Akrilamida menjadi gel

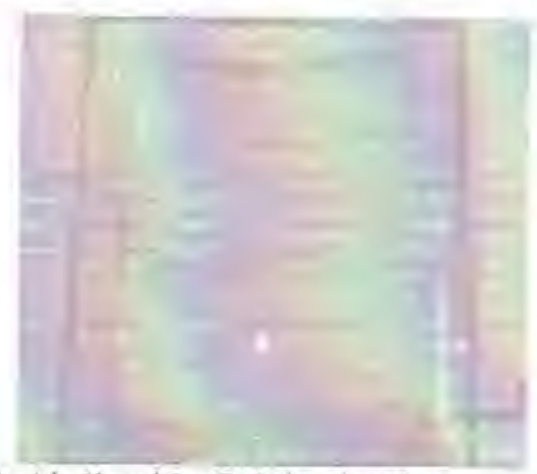

C. Akrilamida Gel dan bening

Gambar 11. Sample Akrilamida dengan

dicampurkan methylene orange

\section{KESIMPULAN}

Dari hasil percobaan tersebut alat fotoreaktor dapat mendegradasikan warna suatu sampel dari warna semula merah menjadi bening tak berwarna dan perubahan wujud sampel dari cair menjadi padat menyerupai gel pada suhu $54,83{ }^{\circ} \mathrm{C}$. Panas maksimal alat yang dapat dicapai adalah $86,17^{\prime \prime} \mathrm{C}$ pada menit ke 14.59 .

\section{DAFTAR PUSTAKA}

1. Tedi Hudaya, Hendy Kartawijaya, dan Yulia, Pengolahan Limbah Cair Warna Tekstil yang Bersifat Non-biodegradable dalam Multi-lamp Bubble Column Photoreactor, Prosiding Seminar Nasional Teknik Kimia "Kejuangan". Yogyakarta. (2010).
2. Lakafin Pratama, Tugas akhir judul "Rancang bangun photoreaktor berbasis mikrokontroler".(2011).

3. (Hyperlink reference not valid), Diakses pada tanggal 3 Januari 2013,22.30.

4. Anonim,(http://elektronikadasar,web.id/ko - mponen/sensor-tranducer/sensor cahayaldr-light-dependent-resistor/). Diakses pada tanggal 20 Juni 2013, 21,30.

5. http://deoebp.blogspot.com/2011/08/keypa d-3x4-atmega 16.html).Diakses pada tanggal 3 Januari 2013,21.00.

6. Heri Andriant. Pemrograman Mikrokontroler AVR Atmega 16 Menggunakan Bahasa C. Informatika . Bandung. (2010). 